\title{
SURGICAL PATIENT SAFETY IN A PUBLIC TEACHING HOSPITAL
}

\section{SEGURANÇA DO PACIENTE CIRÚRGICO EM UM HOSPITAL PÚBLICO DE ENSINO}

\author{
Isadora Braga CALEGARI ${ }^{1}$, Karoline Faria de OLIVEIRA ${ }^{2}$; \\ Quênia Cristina Gonçalves da SILVA ${ }^{3}$; Aldenora Laísa Paiva de Carvalho CORDEIRO ${ }^{4}$; \\ Regiane Evangelista Chaves ISIDORO ${ }^{5}$; Lúcia Aparecida FERREIRA ${ }^{6}$; \\ Maria Beatriz Guimarães FERREIRA ${ }^{7}$; Maria Helena BARBOSA ${ }^{8}$ \\ 1. Residente no Programa de Residência Multiprofissional na Saúde do Adulto da Universidade Federal do Triângulo Mineiro - UFTM; \\ 2. Mestre em Atenção à Saúde. Enfermeira do Instituto Ciências da Saúde - ICS - UFTM; 3. Mestre em Atenção à Saúde. Enfermeira do \\ Hospital de Clínicas da UFTM; 4- Mestre em Atenção à Saúde. Enfermeira do Hospital de Clínicas da UFTM; 5- Mestranda em \\ Atenção à Saúde pela UFTM; 6- Doutora em Enfermagem. Professor Adjunto do ICS da UFTM; 7- Doutora em Ciências. Pós- \\ doutoranda do Programa de Pós-Graduação em Atenção à Saúde da UFTM; 8- Doutora em Enfermagem na Saúde do Adulto. Professor \\ Associado do ICS da UFTM. mhelena331@ @otmail.com
}

\begin{abstract}
: to identify the adherence of the surgical team to the safety procedures recommended for safe surgery and to correlate the scores to the time of surgery. This is a observational and quantitative field study performed at the Surgical Center Unit of a public teaching hospital in Minas Gerais, Brazil, with a sample of 80 patients. For the data collection, the instrument Standard Model for Verification of Surgical Patient Safety was applied for a period of three months. The mean general score of the instrument was 60.4 points, with maximum and minimum values of 71.4 and 46.3 , respectively. The mean surgical safety scores assessed were 75.2 points before anesthetic induction; 67.1 points before the surgical incision and 23.1 points before leaving the operating room. The instrument count performed by at least two people, audibly, with separation of items during count, was not performed in $100 \%$ of the surgical procedures observed. The count of materials used in the procedure in an individualized way was not performed in $100 \%$ of the surgical procedures. The mean surgery time found was 158.2 minutes. The bivariate analysis showed that there was no statistically significant correlation between the time of surgery and the surgical safety scores. It was evidenced a low adhesion of the surgical team to the safety procedures recommended by ANVISA. There was no correlation between the surgical time and the scores found.
\end{abstract}

KEYWORDS: Patient Safety. Operating Rooms. Checklist.

\section{INTRODUCTION}

Patient safety, according to the World Health Organization (WHO), refers to reduction of risk and harm to the patient, associated with health care (WHO, 2009). Safety is one of the basic criteria for ensuring the quality of care to the patient (VENDRAMINI et al., 2010), however, it represents one of the greatest challenges to quality excellence in the health sector (GONÇALVES et al., 2012). The possibility of human error becomes one of the main factors related to this issue.

The error can be defined as the event or circumstance that could have resulted, or that resulted in unnecessary harm to the patient, and may come from intentional acts or not. When this incident reaches the patient and causes damage, it is considered an incident with damage or adverse event (AE) (WHO, 2012).

A study carried out in three public teaching hospitals in Brazil showed a proportion of avoidable surgical AEs of $68.3 \%$, in addition to permanent disability or death in one in five patients (MOURA; MENDES, 2012). Another Brazilian investigation context with prevalence of AEs has shown that the most frequent preventable conditions are related to surgery (MENDES et al., 2013).

In order to prevent risks and potential harm to patient safety, the surgical team, which includes surgeons, anesthesiologists, nursing staff, technicians and other members of the operating room involved in the surgical procedure, should use the Surgical Safety Checklist, which aims to strengthen accepted safety practices and promote better communication and effective work of the multidisciplinary team (WHO, 2014).

The instrument was recommended by the WHO and is included in the actions recommended by the National Agency of Sanitary Surveillance (ANVISA) in Brazil, whose main objective is to coordinate programs and activities to prevent adverse events (MOURA, 2012).

Evidence suggests that adopting the checklist reduces patient morbidity and mortality, improves communication and teamwork, reduces surgery time, and can reduce hospital costs (CADMAN, 2016). 
In this perspective, this study aimed to identify the adherence of the surgical team of a public teaching hospital to the safety procedures recommended for safe surgery and to correlate the scores to the surgery time.

\section{MATERIAL AND METHODS}

This is a observational, analytical, crosssectional, prospective and quantitative study. The study was conducted at the SC (Surgical Center) of a public teaching hospital, located in Minas Gerais, Brazil. The institution is a reference for 27 municipalities, which make up the macro-region of the South Triangle of the State. The SC has 12 operating rooms (OR), including the following specialties: cardiology, otorhinology, pediatrics, orthopedics, urology, plastic surgery, gastrology, neurology, ophthalmology, gynecology and obstetrics, general surgery, thoracic surgery, proctology, vascular surgery and head and neck surgery. For the study in question, the orthopedic specialty was selected because it is the surgical type with the highest prevalence of monthly surgeries in the institution.

The target population was the patients submitted to the orthopedic surgical procedure who accepted to participate in the study by signing the Free and Informed Consent Form (FICF), which was prepared in two copies, one of which was retained by the research participant and the other was filed by the researcher in charge. The inclusion criteria were: orthopedic surgeries inserted into the surgical (elective) schedule. Emergency surgeries or surgeries from other specialties were excluded.

For data collection, the instrument called "Standard Model for Verification of Surgical Patient Safety (SM-VSPS) - checklist type" (MOREIRA, 2012), validated in Brazil, was applied, based on the WHO and ANVISA Surgical Checklist (WHO, 2009). This instrument contemplates the essential objectives for safe surgery available in the handbook "Safe Surgeries Saves Lives" and covers additional protection and prevention measures recommended by the Brazilian Society of Surgical Center, Anesthetic Recovery and Material and Sterilization Center Nurses (SOBECC in Portuguese).

The instrument has three parts:

- 1st part: refers to procedures that are observed in the preoperative period and before anesthetic induction, composed of 24 questions and denominated "Part A".

- 2nd part: refers to the procedures that are observed in the intraoperative period and before surgical incision, composed of 25 questions and denominated "Part B".

- 3rd part: refers to the procedures that are observed in the intraoperative period and before the patient leaves the OR, composed of 16 questions and denominated "Part C".

Data collection was performed by the researcher in charge through systematic observation of the surgical procedure, following the Checklist, which guides a team-based verbal interaction as a means of confirming whether the appropriate standards of care are being ensured for each patient (WHO, 2014).

For the sample size calculation, a positive Pearson's correlation coefficient, $r=0.3$, was considered between surgery time and the total score of the instrument used, for a significance level of 0.05 and a type II error of 0.2 , resulting in an aprioristic power of $80 \%$. Using the PASS 2002 application, a minimum sample size of $n=84$ was reached. Including losses of $20 \%$, the maximum number of interview attempts to be considered would be $n=100$ surgeries.

Data collection was performed in three months, from February to March and July to September 2014. The researcher in charge for data collection was previously trained and performed the pilot data collection with five patients to standardize the procedure. During the period, 100 elective procedures of orthopedic surgery were approached, obtaining 20 denials of participation. The final sample was 80 surgeries.

The data collected were stored in an electronic database of the Excel $\AA$ for Windows $\mathrm{Xp}{ }^{\circledR}$ program, validated by double typing and exported to SPSS® software version 20 for processing and analysis.

First, the calculation of the score was calculated by using the formula [(number of yes/number of items - number of not applicable) * 100], in which the numbers of yes represent the number of items that were followed by the team and the number of items represents the total number of items of the instrument or number of items of each part of the instrument. There is no cutoff point for determining optimal adhesion of instrument recommendations. Scores close to $100 \%$ were considered satisfactory.

The overall score of the instrument, the score of part A- patient identification and procedures (before anesthetic induction), the score of part B - before the surgical incision and the score of part C - before the patient left the OR were calculated. Statistical analysis was used for descriptive analysis based on absolute and 
percentage frequencies for categorical variables and centrality (mean or median) and dispersion (standard deviation or minimum and maximum) measurements for the numerical variables.

Spearman's non-parametric correlation test was used to measure the intensity of the association between two variables. The surgery time was correlated with the surgical safety scores. The level of significance adopted for this analysis was $95 \%$ (p $<0.05)$.

This study is part of a larger study entitled "Adaptation and Validation of an Instrument for Verification of Surgical Patient Safety" approved by the Ethics and Research Committee of the Federal University of the Triângulo Mineiro/UFTM under opinion number 2034.

\section{RESULTS}

The sample was represented by 80 patients submitted to the elective orthopedic surgical procedure.
Surgical orthopedic procedures were categorized according to the procedure site or the type of surgery, as shown in Table 1.

It was observed a greater frequency of surgical procedures for correction of lower and upper limb fractures, among them tibial plateau fracture, femur fracture, transtrochanteric fracture, foot, lateral malleolus, patella and humerus fracture and diaphyseal fracture of radius and ulna.

The surgical procedures involving lower limbs include charcot's disease, tendon stretching, acquired crooked foot surgery, extensor mechanism realignment, recurrent dislocation, osteotomy of the bones of the foot, congenital crooked foot, tarsal coal surgery, surgical debridement and surgical wound exploration.

The surgical procedures involving upper limbs include scapulo-lunate dislocation, shoulder dislocation, lesion debridement, hand injury excision, ulnar neurorrhaphy, surgical treatment of hand syndactyly, carpal tunnel syndrome and bilateral triceps stretching.

Table 1. Distribution of the frequency of patients submitted to orthopedic surgery according to site/type of surgery. Uberaba (MG), 2015.

\begin{tabular}{lll}
\hline Type of Surgery & Observed Frequency & Percentage (\%) \\
\hline Correction of Fracture of Limbs & 34 & 42.5 \\
Lower limbs & 12 & 15.0 \\
Upper limbs & 10 & 12.5 \\
Withdrawal of Synthesis Material & 6 & 7.5 \\
Hips & 3 & 3.8 \\
Arthrodesis & 2 & 2.5 \\
Resection of Tumor of Soft Parts & 2 & 2.5 \\
Ligament Reconstruction & 2 & 2.5 \\
External Fixer Handling & 1 & 1.3 \\
Articular Exploration & 1 & 1.3 \\
Spine & 1 & 1.3 \\
Resection of Synovial Cyst & 1 & 1.3 \\
Tendon Transfer & 1 & 1.3 \\
Injury Exploration & 1 & 1.3 \\
Resection of Tumor of Soft Parts & 1 & 1.3 \\
Articular Drainage & 1 & 1.3 \\
Amputation & 1 & 1.3 \\
TOTAL & 80 & 100 \\
\hline
\end{tabular}

The mean general score of the instrument was 60.4 points, with maximum and minimum values of 71.4 and 46.3 , respectively. Surgical safety scores assessed before anesthetic induction, before surgical incision and before leaving the OR are shown in Table 2.
The period that shows a greater concern regarding surgical safety, that is, that presented lower score, refers to the procedures performed in the third part of the instrument, before the patient leaves the OR, which obtained a mean of 27.1 (SD = 9.4) dots. 
Table 2. Surgical Safety Scores. Uberaba (MG), 2015.

\begin{tabular}{lllll}
\hline Score & General & $\begin{array}{l}\text { Before anesthetic } \\
\text { induction }\end{array}$ & $\begin{array}{l}\text { Before } \\
\text { incision }\end{array}$ & $\begin{array}{l}\text { surgical } \\
\text { Beaves the OR }\end{array}$ \\
\hline Minimum & 46.3 & 54.6 & 40.9 & 7.7 \\
Maximum & 71.4 & 90.5 & 88.9 & 56.3 \\
Mean & 60.4 & 75.2 & 67.1 & 27.1 \\
Standard Deviation & 5.7 & 7.7 & 9.1 & 9.4 \\
\hline
\end{tabular}

In the first part of the instrument, items A.14 (procedure site demarcated by surgeon), A.17 (patient signed surgical consent), A.22 (team verified the functioning of electric scalpel) and A.23 (team checked the functioning of the aspirator), obtained low adhesion by the surgical team.

The demarcation of the site of the surgical procedure by the surgeon (item A.14) was not observed in $85 \%$ of patients undergoing orthopedic surgery.

Item A.17 evaluates whether the patient signed the surgical consent. In $90 \%$ of the procedures, the consent was not signed. The items A.22 and A.23, referring to the verification of functioning of the electric scalpel and the aspirator by the team, were not checked in 52.5\% and 51.3\% of the surgical procedures, respectively.

The second part of the instrument refers to procedures performed before the surgical incision. Item B.1 provides for the accomplishment of the surgical time out, an event not performed in $100 \%$ of the surgical procedures.

The oral presentation of the team involved in the procedure, (item B.2), not performed in $91.3 \%$.

Item B.13, which observes the body temperature monitoring, was not performed in $97.5 \%$ of the surgeries. In addition to this, item B.14 observes the use of some method to maintain body temperature. In $87.5 \%$ of the surgeries no method was used to maintain the temperature, except the use of surgical fields.
Verbal confirmation with the anesthesiologist on the risk of blood loss, expressed in item B.20, was not performed in $56.3 \%$ of the surgeries and the instrument count before the surgical incision was not performed in $63.8 \%$ of the surgeries observed.

The third part of the instrument observes the adherence by the surgical team to the safety procedures performed before the patient leaves the operating room, which obtained a low surgical safety score. The instrument count performed by at least two audible individuals with separation of the items during the count was not performed in $100 \%$ of the surgical procedures observed.

The count of compresses and sharp material, needles and instruments in an individualized manner was not performed in $98.8 \%$ and $100 \%$ of surgical procedures, respectively.

Items C.11, C.12 and C.13, referring to the verbal confirmation of the procedure performed by the surgeon, anesthesiologist and nursing professional was not confirmed in $85 \%, 86.3 \%$ and $92.5 \%$ of the procedures, respectively.

The mean time of surgery was $158.2(\mathrm{SD}=$ 75.0) minutes. The procedure of shorter duration was of 20 minutes and the one of greater duration of 360 minutes. For Spearman's non-parametric correlation coefficient $(\rho)$, the bivariate analysis showed that there was no statistically significant correlation between the time of surgery and the surgical safety scores (Table 3 ).

Table 3. Distribution of correlational bivariate analysis between surgical safety scores and the variable time of surgery. Uberaba (MG), 2015.

\begin{tabular}{lllll}
\hline $\begin{array}{l}\text { Surgery } \\
\text { Time }\end{array}$ & General Score & First part $*$ & Second part $* *$ & Third part *** \\
\hline $\mathbf{\rho}$ & 0.16 & -0.14 & 0.18 & 0.10 \\
$\mathbf{p}$ & 0.15 & 0.89 & 0.10 & 0.34 \\
\hline Score before anesthetic induction; $* *$ Score before surgical incision; $* * *$ Score before the patient leaves the OR
\end{tabular}

\section{DISCUSSION}

The present study identified low adherence to safety procedures performed before the patient leaves the operating room, evidenced by the low surgical safety score.

The safety procedures performed before anesthetic induction in the first part of the instrument showed some items that obtained low 
compliance by the surgical team, of which procedure site demarcated by surgeon, patient signed surgical consent, team verified the functioning of electric scalpel and team checked the functioning of the aspirator. Considering the verification item referring to the demarcation of the procedure site, the results obtained in this study highlighted the importance of performing this action, since it was not performed in $85 \%$ of the procedures, allowing the occurrence of adverse events.

This result corroborates a study that evaluated the adherence of the surgical and nursing team in the implantation of the protocol of demarcation of the surgical site, in which $84.7 \%$ of the professionals stated that they had not marked laterality. This action is part of the demarcation procedure by the surgeon (SANTOS; CAREGNATO; MORAES, 2013).

A study that evaluated the degree of knowledge of Brazilian orthopedists about the WHO Safe Surgery Protocol showed that $40.8 \%$ of orthopedists reported experiencing surgery in the wrong patient or in the wrong place. This same study identified that $36.5 \%$ of orthopedists reported not marking the surgical site before referring the patient to the surgical center (MOTTA FILHO et al., 2013).

It is also observed that in surgical specialties involving double laterality, such as orthopedics, the possibility of error is even greater (AMAYA et al., 2015).

Checking surgical consent is highly recommended by WHO. Contrary to the results obtained in this study, the literature indicates that consent for surgery was checked in $91.35 \%$ of the surgical procedures analyzed (CARVALHO et al., 2014). In another study carried out in the surgical area of Orthopedics and Traumatology of the Hospital Santa Cruz de Liencres in Cantabria, Spain, it was observed that informed consent was reported in $91.4 \%$ of the procedures (MANRIQUE et al., 2015).

Equipment check is a procedure performed before the anesthetic induction, contemplated in the instrument used in this study (SM-VSPS) and in the WHO Surgical Safety Checklist. The WHO recommendation for the anesthesiologist or anesthesiology team refers to performing a formal inspection of the anesthetic equipment, in which the use of a mnemonic is useful, so as to contemplate the ABCDEs check - an examination of the airway equipment, breathing system (including oxygen and inhalation agents), suction, drugs and devices, medicines, equipment and emergency care to confirm their availability and functioning (WHO, 2009).

A study carried out in a private hospital in the city of São Paulo observed the non-checking of materials and equipment used in surgical procedures by $80.7 \%$ of the professionals in the operating room (BOHOMOL; TARTALI, 2013), which corroborates with the results of the research in question.

The second part of the instrument comprised the procedures performed before the surgical incision.

Surgical time out occurs just before the skin incision, during which the surgical team presents by name and function. Then, it is performed the confirmation of the patient, location, procedure and correct positioning, surgical site, prophylaxis of venous thromboembolism, presence of the diagnostic image, confirmation of sterilization of equipment and anticipation of any critical steps (WHO, 2009; PANESAR et al., 2011).

The application of the checklist in 40,000 surgeries of a university hospital in France found that the professionals have difficulty in sharing information orally in the surgical time out (RATEAU et al., 2011).

The present study demonstrated that in $91.25 \%$ of the procedures the team did not present themselves by name and function before the surgical incision. This result is much more significant when compared to a study performed in a surgical center of a reference teaching hospital in southern Brazil, in which the team presented themselves by name and function in $48.2 \%$ of the procedures analyzed (AMAYA et al., 2015).

The verification items regarding temperature monitoring and maintenance presented low adherence by the surgical team, being less than $20 \%$. Perioperative patient's body temperature monitoring is recommended by the Association of Perioperative Registered Nurses (ASSOCIATION OF PERIOPERATIVE REGISTERED NURSES, 2009).

The implementation of methods to maintain patient's body temperature for the prevention of complications associated with hypothermia is fundamental in the perioperative period (POVEDA; MARTINEZ; GALVÃO, 2012) because hypothermia in this period is common and can cause complications such as coagulation and changes in platelet function, increased cardiac morbidity and surgical site infection, as well as elevated incidence of pressure ulcer (POVEDA; CLARK; GALVÂO, 2013). 
The verbal confirmation about the risk of blood loss is an item highly recommended by the WHO Safe Surgery Protocol, and the surgical team should be prepared for this situation. With regard to the risk of blood loss, the team must ensure that appropriate intravenous access is established, ensure the availability of compatible blood products and plan fluid replacement (WHO, 2009). Results of the study that assessed adherence to the WHO Safe Surgery Checklist noted that the level of verification of the risk of blood loss was $72 \%$ (FREITAS et al., 2014).

The results of this research verified a low surgical safety score as a result of lower levels of adherence by the surgical team to the safety items contemplated in the third part of the instrument.

There was no significant adherence to the instrument count in this study, which evidenced that in $63.8 \%$ of the surgeries the count was not performed. On the other hand, a study with 3033 patients in a hospital in Spain found that, before the patient left, the instrumental nurse confirmed verbally the accuracy of the final recount of the material and the needles in $77.9 \%$ of cases (MANRIQUE et al., 2015).

The results of this research verified that in 98.8\% of the procedures the number of compresses was not counted before the patient left the operating room. This result can be compared to a study on the surgical patient safety, in which the counts of gas and compresses were low, being $18.4 \%$ in the analyzed procedures (MANRIQUE et al., 2015). A research that evaluated the information recording and the content of safe surgical checklists in the orthopedic specialty found that the count of surgical instruments and needles, compresses and gauzes ranged from $47.9 \%$ to $77.4 \%$ (AMAYA et al., 2015).

A study that evaluated nursing professionals' knowledge about adverse events in surgical patients showed that $96.7 \%$ of the professionals considered the nonconference of compresses in open surgeries as an adverse event (BOHOMOL; TARTALI, 2013).

It was possible to verify that the checking of the compresses before the patient leaves the operating room is not inserted in the institutional culture of the field of study in question and is not adopted like a safety check item.

Compresses and instruments can be retained during any surgical procedure in any cavity of the body, regardless of magnitude or complexity (WHO, 2009).

Before the patient leaves the operating room, the surgeon, the anesthesiologist and the nursing team should review the recovery and the postoperative management plan, focusing in particular on the intraoperative or anesthetic issues, which may affect the patient. The objective of this stage is the efficient and adequate communication of critical information to the entire team (WHO, 2009). Communication failures among professionals of the surgical team may impair the quality of care provided to the surgical patient.

There was no significant correlation between the surgery time and the surgical safety scores. This fact may have occurred due to the fact that the same specialty contemplates different complexities and very variable surgical times.

A study in which 80 checklists were evaluated during the surgical time out ("Time Out") and 81 before the patient left the operating room ("Sign Out") verified that adherence to checklist items was greater in risk interventions when compared to lower risk interventions (CULLATI et al., 2013). Longer surgeries cover a greater number of critical steps, which could justify a greater concern of the team in using a checklist (FREITAS et al., 2014).

The introduction of a checklist in the routine of surgical care may contribute to the verification of critical or neglected safety items for the establishment of safe surgery.

A qualitative field study performed at the surgical center of a school hospital in the interior of the state of São Paulo showed that the use of the checklist provided more safety to the surgical process for $80 \%$ of the subjects interviewed, in which it was pointed out that the checklist reduces risks and possible complications, standardizes conducts and reviews safety steps, enables better understanding of the process and provides safety to the whole team (PANCIERI et al., 2013).

Failure to adhere to safety procedures during surgical care brings a wide range of risks and harm to the patient, which are avoidable through the use of the WHO Safe Surgery Protocol. The Safe Surgery Checklist is a worldwide strategy strongly recommended to establish a safe surgical environment and aims to involve the staff in the verification of safety items in order to increase adherence to safety procedures.

In this context, it is important to incorporate the Safe Surgeries Saves Lives Program into the institution as a health care method aimed at the quality of care, patient safety in the surgical environment and adequate training of the surgical team to perform safe actions. The implementation of a checklist can help the surgical team to perform 
safe actions that reduce the gaps identified in surgical care.

A limitation of the study found was the collection of data in a surgical specialty, which restricts the results found in this area of performance. It is proposed that new research with similar methodologies be performed in other surgical specialties.

\section{CONCLUSIONS}

It is possible to verify the adherence of the surgical team to the safety procedures recommended for safe surgery in the orthopedic specialty by the institution or service where this investigation was performed.
The surgical safety score showed low adherence by the surgical team to safety procedures performed before the patient leaves the operating room. The applied research showed, above all, a deficiency on the part of the surgical team to check the safety items recommended by ANVISA for a safe surgery.

There was no correlation between the surgical time and the scores found.

The results show the need to implement a surgical checklist, with the purpose of modifying the institutional safety environment, with monitoring of the indicators generated, in order to support the care provided and the planning of strategies to guarantee a safe and effective care.

RESUMO: Identificar a adesão da equipe cirúrgica aos procedimentos de segurança preconizados para cirurgia segura e correlacionar os escores encontrados ao tempo de cirurgia. Estudo observacional e quantitativo, realizado na Unidade de Centro Cirúrgico de um hospital público de ensino de Minas Gerais, Brasil, com amostra de 80 pacientes. Para a coleta de dados, foi aplicado o instrumento Modelo Padrão para Verificação da Segurança do Paciente Cirúrgico por um período de três meses. O escore geral médio do instrumento foi de 60,4 pontos, com valores máximos e mínimos de 71,4 e 46,3, respectivamente. Os escores médios de segurança cirúrgica foram: 75,2 pontos antes da indução anestésica; 67,1 pontos antes da incisão cirúrgica e 23,1 pontos antes de sair da sala de operação. Em $100 \%$ dos procedimentos cirúrgicos não foi realizado a contagem dos instrumentais por pelo menos duas pessoas, de forma audível, com separação dos itens durante a contagem. A contagem de materiais utilizados no procedimento de maneira individualizada não foi realizada em $100 \%$ dos procedimentos cirúrgicos. O tempo de cirurgia médio encontrado foi de 158,2 minutos. A análise bivariada demonstrou que não houve correlação estatisticamente significativa entre o tempo de cirurgia com os escores de segurança cirúrgica. Foi evidenciada uma baixa adesão da equipe cirúrgica aos procedimentos de segurança recomendados pela ANVISA. Não houve correlação entre o tempo cirúrgico e os escores encontrados.

PALAVRAS-CHAVE: Segurança do Paciente. Salas Cirúrgicas. Lista de Checagem.

\section{REFERENCES}

AMAYA, M. R. et al. Análise do registro e conteúdo de checklists para cirurgia segura. Escola Anna Nery, Curitiba, v. 19, n. 2, p. 246-251, 2015.

ASSOCIATION OF PERIOPERATIVE REGISTERED NURSES. Recommended practices for the prevention of unplanned perioperative hypothermia. In: Association of perioperative Registered Nurses. Perioperative standards and recommended practices. Denver (USA): Association of periOpertive Registered Nurses; 2009. 491-504.

BOHOMOL, E.; TARTALI, J. A. Eventos adversos em pacientes cirúrgicos: conhecimento dos profissionais de enfermagem. Acta Paul Enfermagem, São Paulo, v. 26, n. 4, p. 376-381, 2013. https://doi.org/10.1590/S010321002013000400012

CADMAN, V. The impact of surgical safety checklists on theatre departments: a critical review of the literature. J Perioper Pract. North Yorkshire, v. 26, n. 4, p. 62-71, 2016.

CARVALHO, L. K. C. A. A. et al. Análise dos procedimentos realizados pela equipe de enfermagem na recepção dos pacientes no centro cirúrgico. Revista Interdisciplinar, Teresina, v. 7, n. 4, p. 30-38, 2014. 
CULLATI, S. et al. Is the Surgical Safety Checklist successfully conducted? An observational study of social interactions in the operating rooms of a tertiary hospital. BMJ Quality and Safety, London, v. 22, p. 639-646, 2013. https://doi.org/10.1136/bmjqs-2012-001634

FREITAS, M. R. et al. Avaliação da adesão ao checklist de cirurgia segura da OMS em cirurgias urológicas e ginecológicas, em dois hospitais de ensino de Natal, Rio Grande do Norte, Brasil. Cadernos de Saúde Pública, Rio de Janeiro, v. 30, n. 1, p. 137-148, 2014.

GONÇALVES, L. A. et al. Alocação da equipe de enfermagem e ocorrência de eventos adversos/incidentes em unidade de terapia intensiva. Revista da Escola de Enfermagem da USP, São Paulo, v. 46 (esp), p. 71-77, 2012.

MANRIQUE, B. T. et al. Segurança do paciente no centro cirúrgico e qualidade documental relacionadas à infecção cirúrgica e à hospitalização. Acta Paul Enfermagem, São Paulo, v. 28, n. 4, p. 355-360, 2015. https://doi.org/10.1590/1982-0194201500060

MENDES, W. et al. Características de eventos adversos evitáveis em hospitais do Rio de Janeiro. Revista da Associação Médica Brasileira, v. 59, n. 5, p. 421-428, 2013. https://doi.org/10.1016/j.ramb.2013.03.002

MOREIRA, T. M. Adaptação e validação de um instrumento para verificação de segurança do paciente. 2012, 122 f Dissertação (Mestrado em Atenção à Saúde) - Programa de Pós Graduação em Atenção à Saúde, Universidade Federal do Triângulo Mineiro, Uberaba, 2012.

MOTTA FILHO, G. R. et al. Protocolo de Cirurgia Segura da OMS: o grau de conhecimento dos ortopedistas brasileiros. Revista Brasileira de Ortopedia, São Paulo, v. 48, n. 6, p. 554-562, 2013.

https://doi.org/10.1016/j.rbo.2013.08.002 https://doi.org/10.1016/j.rboe.2013.12.010

MOURA, M. L. O.; MENDES, W. Avaliação de eventos adversos cirúrgicos em hospitais do Rio de Janeiro. Revista Brasileira de Epidemiologia, São Paulo, v. 15, n. 3, p. 523-535, 2012. https://doi.org/10.1590/S1415790X2012000300007

ORGANIZAÇÃO MUNDIAL DA SAÚDE. Manual de Implementação Lista de Verificação de Segurança Cirúrgica da OMS 2009/ Organização Mundial da Saúde Manual de Implementação - Lista de Verificação de Segurança Cirúrgica da OMS 2009 - Cirurgia Segura Salva Vidas; tradução de OPAS - Brasília: Organização Pan Americana da Saúde; Agência Nacional de Vigilância Sanitária, 2014. 20 p.

ORGANIZAÇÃO MUNDIAL DE SAÚDE - OMS. Segundo desafio global para a segurança do paciente: Cirurgias seguras salvam vidas. Brasília (DF): Agência Nacional de Vigilância Sanitária; 2009.

PANCIERI, A. P. et al. Checklist de cirurgia segura: análise da segurança e comunicação das equipes de um hospital escola. Revista Gaúcha de Enfermagem, Porto Alegre, v. 34, n. 1, p. 71-78, 2013. https://doi.org/10.1590/S1983-14472013000100009

PANESAR, S. S. et al. Can the surgical checklist reduce the risk of wrong site surgery in orthopaedics? - Can the checklist help? Supporting evidence from analysis of a national patient incident reporting system. Journal of Orthopaedic Surgery and Research, London, v. 6, p.18, 2011. https://doi.org/10.1186/1749-799X-6-18

POVEDA, V. B.; CLARK, A. M.; GALVÃO, C. M. A systematic review on the effectiveness of prewarming to prevent perioperative hypothermia. Journal of Clinical Nursing, Malden, v. 22, n. 7-8, p. 906-918, 2013. https://doi.org/10.1111/j.1365-2702.2012.04287.x

POVEDA, V. B.; MARTINEZ, E. Z.; GALVÃO, C. M. Métodos ativos de aquecimento cutâneo para a prevenção de hipotermia no período intraoperatório: revisão sistemática. Revista Latino-Americana de Enfermagem, Ribeirão Preto, v. 20, n. 1, 9 telas. Disponível em: $<$ http://www.scielo.br/pdf/rlae/v20n1/pt_24.pdf.>. Acesso em: junho 2015. 
RATEAU, F. et al. Check-list "Sécurité du patient au bloc opératoire": une anée d'expérience su 40000 interventions au centre hospitalier de Nice. Annales Françaises d'Anesthésie et de Réanimation, v. 30, n. 6, p. 479-483,. 2011. https://doi.org/10.1016/j.annfar.2011.04.003

SANTOS, C. M.; CAREGNATO, R. C. A.; MORAES, C. S. Equipe cirúrgica: adesão à meta 1 da cirurgia segura. Revista SOBECC, São Paulo, v. 18, n. 4, p. 47-56, 2013.

VENDRAMINI, R. C. R. et al. Segurança do paciente em cirurgia oncológica: experiência do Instituto do Câncer do Estado de São Paulo. Revista da Escola de Enfermagem da USP, São Paulo, v. 44, n. 3, p. 827832, 2010. https://doi.org/10.1590/S0080-62342010000300039

WORLD HEALTH ORGANIZATION. Patient safety research: introductory course - Session 1 . What is patient safety? [place unknown]: WHO; 2012 [cited 2014 July 15]. Available from:

http://www.who.int/patientsafety/research/online_course/en/. 